\title{
The Osmotic Requirements for Growth of Mycoplasma
}

\author{
BY R. H. LEACH \\ The Wellcome Research Laboratories, Beckenham, Kent
}

(Received 27 July 1961)

\begin{abstract}
SUMMARY
Alteration of the tonicity of a modified Edward medium by means of $\mathrm{NaCl}$ or other solutes resulted in very marked effects on the growth of several Mycoplasma strains. With both fluid and solid media, all grew best at about 10 atmospheres osmotic pressure (water activity, $a_{w}, 0.9925$ ). The most exacting species, Mycoplasma gallisepticum, failed to grow outside the range $6 \cdot 8-14$ atmospheres $\left(a_{w} 0 \cdot 995-0 \cdot 990\right)$, while the least exacting, $M$. laidlawii, multiplied at up to 27 atmospheres $\left(a_{w} 0 \cdot 980\right)$. Osmotic requirements were not appreciably altered by serial growth in hypertonic or hypotonic media but were, to some extent, conditioned by the serum content of the medium.
\end{abstract}

\section{INTRODUCTION}

The plasticity and pleomorphism of organisms of the Mycoplasma group are usually attributed to a lack of a rigid cell wall (Klieneberger \& Smiles, 1942; Klieneberger-Nobel, 1954). This concept is supported by electron micrographic studies (Smith, Hillier \& Mudd, 1948; Klieneberger-Nobel \& Cuckow, 1955) and by evidence that these organisms are deficient in the 'mucocomplex' found in bacterial cell walls (Kandler \& Zehender, 1957; Plackett, 1959). It is generally stated that as a consequence of this deficiency the Mycoplasma are very susceptible to osmotic shock (Freundt, 1952; Chu, Horne \& Cosslett, 1956), although this view has been questioned (Smith \& Sasaki, 1958; Butler \& Knight, 1960a; Adler \& Shifrine, 1960). Very little attention, however, has been paid to the osmotic requirements for growth of Mycoplasma in artificial culture. Rodwell (1956) noted that the tonicity of the medium was critical for Mycoplasma mycoides var. mycoides and Adler \& Shifrine (1960) referred to unpublished observations on the osmotic requirements of avian species. This paper describes investigations of the osmotic requirements for growth of several species of Mycoplasma.

\section{METHODS}

Strains. Mycoplasma mycoides var. mycoides (P.G.1), M. mycoides var. capri (P.G.3), M. laidlawii, strain A (P.G.8), M. bovigenitalium (P.G.12), M. gallinarum (P.G.16) and M.gallisepticum (P.G.31) were obtained from the collection maintained in these Laboratories (Edward \& Freundt, 1956). An egg-adapted (T3) strain of M. mycoides var. mycoides was obtained through the courtesy of Dr S. E. Piercy and Mr G. White. The M.R. strain of an unnamed Mycoplasma species from the respiratory tract of a pig was kindly provided by Dr P. Whittlestone (Cambridge 
Veterinary School). A strain of $M$. bovigenitalium, associated with bovine mastitis, was kindly provided by Mr I. Davidson of the Central Veterinary Laboratory, Weybridge.

Media. Edward medium (Butler \& Knight, 1960 $b$ ) was used for some growth experiments and in the solid form, with $1.2 \%(\mathrm{w} / \mathrm{v})$ agar (New Zealand, Difco), for viable counts. A basal medium of low tonicity ('dilute Edward medium'), prepared by omission of added $\mathrm{NaCl}$ from Edward medium and dilution of the final medium, is described under Results.

Estimation of tonicity. Tonicity was estimated by means of freezing-point depression measurements made with a Beckman-type thermometer. The water vapour values for frozen and for liquid water at a given temperature were obtained from standard tables (Handbook of Chemistry and Physics, 1958). The water activity $\left(a_{w}\right.$; see Scott, 1953, 1956) of any medium was then calculated as the ratio of these two vapour pressure values at the freezing temperature of the medium; $a_{w}$ was converted to osmotic pressure and then adjusted to the theoretical value for $\mathbf{2 5}^{\circ}$ by means of the formulae given by Scott (1956).

The tonicity of a medium of known $a_{w}$ was raised to required values by addition of either $\mathrm{NaCl}, \mathrm{KCl}, \mathrm{Na}_{2} \mathrm{SO}_{4}$, sucrose, or a balanced salts solution $(\mathrm{NaCl}$ : $\mathrm{KCl}: \mathrm{Na}_{2} \mathrm{SO}_{4}: \mathrm{MgCl}_{2}$ in molal ratios $\left.5: 3: 1: 1\right)$ by using the tables of Robinson \& Stokes (1955) as described by Scott $(1953,1956)$. Table 1 shows the actual amounts of solutes used to enhance the tonicity of the dilute Edward medium.

Colony counts. These were performed by the method of Butler \& Knight (1960a). Where samples of Mycoplasma growing in media of varied tonicity were being tested, the dilutions of such samples for viable counts were normally made in dilute Edward medium with osmotic pressure adjusted to 10 atmospheres.

Opacity of suspensions. The opacity of Mycoplasma culture suspensions was measured with a photoelectric nephelometer head and galvanometer (Evans Electroselenium, Ltd., Essex; EEL), using standardized 6 in. $\times \frac{5}{8}$ in. test tubes and reading against the EEL Perspex standard opaque tube, with blanks of uninoculated medium. For each strain, growth in different media was compared on the basis of maximum degrees of opacity and of arbitrary growth rates based on the rate of change of opacity (nephelometer units/hr.) over the whole of the active growth period. Two strains, Mycoplasma bovigenitalium and $\boldsymbol{M}$. gallinarum, produced in fluid culture an insoluble refractile material characteristic of those Mycoplasma which are able to form 'film and spots' in solid medium (Edward, 1950). This was not considered to affect the validity of the nephelometric tests for the present purposes.

Growth experiments. Inocula were prepared from surface growth of Mycoplasma on Edward agar medium suspended in dilute Edward medium. For growth curves measured by viable counts, $10 \mathrm{ml}$. lots of test media contained in $1 \mathrm{oz}$. screw-capped bottles were seeded with $0.1 \mathrm{ml}$. of suspensions adjusted to give initial viable counts of about $10^{5}$ viable units $/ \mathrm{ml}$. After inoculation, cultures were incubated at $37^{\circ}$ in air, and at intervals $0.1 \mathrm{ml}$. samples were taken for viable counts. For experiments in which growth was measured by nephelometry, approximately 10 times larger inocula were used and the inoculated cultures were contained in EEL 6 in. $\times \frac{5}{8}$ in. calibrated tubes with aluminium caps. These were incubated in a $37^{\circ}$ water bath and removed at intervals for opacity readings in the nephelometer. 


\section{RESULTS}

Freezing-point measurements showed that Edward medium had an osmotic pressure of about 10 atmospheres. The ox heart infusion broth on which this medium is based contains $0.5 \%$ (w/v) of added $\mathrm{NaCl}$ (Butler \& Knight, 1960 $\mathrm{b}$ ) and when this $\mathrm{NaCl}$ was omitted the full medium was approximately isotonic with physiological fluids $(6.8$ atmospheres). A $40 \%(\mathrm{v} / \mathrm{v})$ dilution in distilled water of this saltdeficient medium, having an osmotic pressure of $2 \cdot 7$ atmospheres, was used as a standard medium and is referred to throughout this paper as 'dilute Edward

Table 1. Amounts of various solutes added to dilute Edward medium to give required values of tonicity

\begin{tabular}{|c|c|c|c|c|c|c|c|}
\hline \multirow[b]{2}{*}{ Medium } & \multirow{2}{*}{$\begin{array}{c}\text { Water } \\
\text { activity } \\
\left(a_{w}\right) \\
\text { at } 25^{\circ}\end{array}$} & \multirow{2}{*}{$\begin{array}{c}\text { Osmotic } \\
\text { pressure } \\
\text { in atmo- } \\
\text { spheres } \\
\text { (calculated } \\
\text { from } a_{w} \text { ) }\end{array}$} & \multicolumn{4}{|c|}{ Concentration of solutes (g. $/ 100 \mathrm{ml}$. medium) } & \multirow[b]{2}{*}{ Sucrose } \\
\hline & & & $\mathrm{NaCl}$ & $\mathbf{K C l}$ & $\mathrm{Na}_{2} \mathrm{SO}_{4}$ & $\begin{array}{c}\text { Balanced salts } \\
\mathrm{NaCl}: \mathrm{KCl}: \mathrm{Na}_{2} \mathrm{SO}_{4}: \mathrm{MgCl}_{2}\end{array}$ & \\
\hline 1 & 0.998 & $\mathbf{2} \cdot \boldsymbol{\gamma}$ & o & $\mathbf{0}$ & $\mathbf{0}$ & $\mathbf{0}$ & $\mathbf{0}$ \\
\hline 2 & $0 \cdot 997$ & $4 \cdot 1$ & $\mathbf{0 \cdot 1 7}$ & $\mathbf{0 \cdot 2 2}$ & $0 \cdot 33$ & $0 \cdot 084: 0 \cdot 064: 0 \cdot 04,1: 0 \cdot 027$ & $1 \cdot 9$ \\
\hline 3 & 0.995 & $6 \cdot 8$ & 0.52 & 0.67 & 0.99 & $0.25: 0.19: 0.12: 0.082$ & $5 \cdot 6$ \\
\hline 4 & 0.9925 & $10 \cdot 2$ & 0.97 & - & - & - & - \\
\hline 5 & 0.990 & $13 \cdot 6$ & $1 \cdot 4$ & $1 \cdot 8$ & $\mathbf{2 \cdot 8}$ & 0.67 :0.52:0.33:0.22 & 15 \\
\hline 6 & $0 \cdot 980$ & 27 & $3 \cdot 20$ & $4 \cdot 2$ & $7 \cdot 0$ & $1.5: 1.6 \quad: 0.73: 0.49$ & 32 \\
\hline 7 & $0 \cdot 970$ & 41 & 4.95 & - & - & - & - \\
\hline 8 & 0.960 & 55 & $6 \cdot 7$ & $8 \cdot 9$ & 16 & $: 2 \cdot 4 \quad: 1 \cdot 5$ & 63 \\
\hline
\end{tabular}

Table 2. Effect of tonicity of fluid medium on growth of Mycoplasma

Tonicity as osmotic pressure (atmospheres)

\begin{tabular}{|c|c|c|c|c|c|c|c|c|}
\hline Strain of Mycoplasma & Type of measurement & $2 \cdot 7$ & $4 \cdot 1$ & $6 \cdot 8$ & 10 & 14 & 27 & 41 \\
\hline M. laidlawii & $\begin{array}{l}\text { Growth rate* } \\
\text { Maximum opacity } \dagger\end{array}$ & $\begin{array}{l}0.5 \\
13\end{array}$ & $\begin{array}{c}1 \cdot 0 \\
21\end{array}$ & 27 & $\begin{array}{l}1 \cdot 2 \\
36\end{array}$ & 35 & $\begin{array}{c}0.3 \\
11\end{array}$ & $\underline{0}$ \\
\hline $\begin{array}{l}\text { M. mycoides var. } \\
\text { mycoides, Strain PG } 1\end{array}$ & $\begin{array}{l}\text { Growth rate } \\
\text { Maximum opacity }\end{array}$ & $\begin{array}{l}\mathbf{0} \\
\mathbf{0}\end{array}$ & $\begin{array}{l}0 \cdot 2 \\
9\end{array}$ & $\begin{array}{l}0 \cdot 5 \\
15\end{array}$ & 25 & $\begin{array}{l}0 \cdot 7 \\
24\end{array}$ & $\begin{array}{l}\mathbf{0} \\
\mathbf{0}\end{array}$ & $\begin{array}{l}\mathbf{0} \\
\mathbf{0}\end{array}$ \\
\hline $\begin{array}{l}\text { M. mycoides var. } \\
\text { mycoides, Strain T/3 }\end{array}$ & $\begin{array}{l}\text { Growth rate } \\
\text { Maximum opacity }\end{array}$ & $\begin{array}{l}\mathbf{0} \\
\mathbf{0}\end{array}$ & $\begin{array}{l}0 \\
0\end{array}$ & $\begin{aligned} & 0 \cdot 2 \\
> & 7\end{aligned}$ & $\begin{array}{l}0.7 \\
12\end{array}$ & $0 \cdot 7$ & $\underline{\mathbf{0}}$ & $\underline{0}$ \\
\hline M. mycoides var. capri & $\begin{array}{l}\text { Growth rate } \\
\text { Maximum opacity }\end{array}$ & $\begin{array}{l}0 \cdot 1 \\
13\end{array}$ & $\begin{array}{l}0 \cdot 4 \\
19\end{array}$ & $\begin{array}{l}0 \cdot 5 \\
27\end{array}$ & $\begin{array}{l}0 \cdot 7 \\
29\end{array}$ & $\begin{array}{l}0 \cdot 6 \\
25\end{array}$ & $\begin{array}{l}\mathbf{0} \\
\mathbf{0}\end{array}$ & $\begin{array}{l}\mathbf{0} \\
\mathbf{0}\end{array}$ \\
\hline M. bovigenitalium & $\begin{array}{l}\text { Growth rate } \\
\text { Maximum opacity }\end{array}$ & $\begin{array}{l}\mathbf{0} \\
\mathbf{0}\end{array}$ & $\begin{array}{l}0 \cdot 4 \\
9\end{array}$ & $\begin{array}{l}0 \cdot 4 \\
22\end{array}$ & $\begin{array}{c}0 \cdot 6 \\
32\end{array}$ & 24 & $\begin{array}{l}\mathbf{0} \\
\mathbf{0}\end{array}$ & $\begin{array}{l}\mathbf{0} \\
\mathbf{0}\end{array}$ \\
\hline M. gallisepticum & $\begin{array}{l}\text { Growth rate } \\
\text { Maximum opacity }\end{array}$ & $\begin{array}{l}\mathbf{0} \\
\mathbf{0}\end{array}$ & $\begin{array}{l}\mathbf{0} \\
\mathbf{0}\end{array}$ & $\begin{array}{l}0 \cdot 8 \\
8\end{array}$ & $17^{1 \cdot 1}$ & $1 \cdot 1$ & $\begin{array}{l}\mathbf{0} \\
\mathbf{0}\end{array}$ & $\begin{array}{l}\mathbf{0} \\
\mathbf{0}\end{array}$ \\
\hline M. gallinarum & $\begin{array}{l}\text { Growth rate } \\
\text { Maximum opacity }\end{array}$ & $\begin{array}{l}0 \cdot 5 \\
41\end{array}$ & $\mathbf{3 7}$ & $\begin{array}{ll}1 \cdot 3 \\
38\end{array}$ & $\begin{array}{c}1 \cdot 3 \\
42\end{array}$ & $\begin{array}{l}0 \cdot 7 \\
38\end{array}$ & $\begin{array}{l}\mathbf{0} \\
\mathbf{0}\end{array}$ & $\begin{array}{l}\mathbf{0} \\
\mathbf{0}\end{array}$ \\
\hline $\begin{array}{l}\text { Porcine Mycoplasma, } \\
\text { Strain MR }\end{array}$ & $\begin{array}{l}\text { Growth rate } \\
\text { Maximum opacity }\end{array}$ & $\begin{array}{l}\mathbf{0} \\
\mathbf{0}\end{array}$ & $\begin{array}{r}0 \cdot 3 \\
10 \cdot 5\end{array}$ & $\begin{array}{r}0 \cdot 3 \\
11 \cdot 5\end{array}$ & $\begin{array}{r}0 \cdot 5 \\
17 \cdot 5\end{array}$ & $\begin{array}{l}0 \cdot 5 \\
17\end{array}$ & $\begin{array}{l}\mathbf{0} \\
\mathbf{0}\end{array}$ & $\begin{array}{l}\mathbf{0} \\
\mathbf{0}\end{array}$ \\
\hline
\end{tabular}

* Approximate rate of change (nephelometer units/hr.) during period of active increase in opacity.

$\uparrow$ Nephelometer units. 
medium'. To this, $\mathrm{NaCl}$ or other solutes were added to raise the tonicity to required values (Table 1). Solid medium was prepared from this medium by addition of $1.2 \%(w / v)$ agar (New Zealand, Difco).

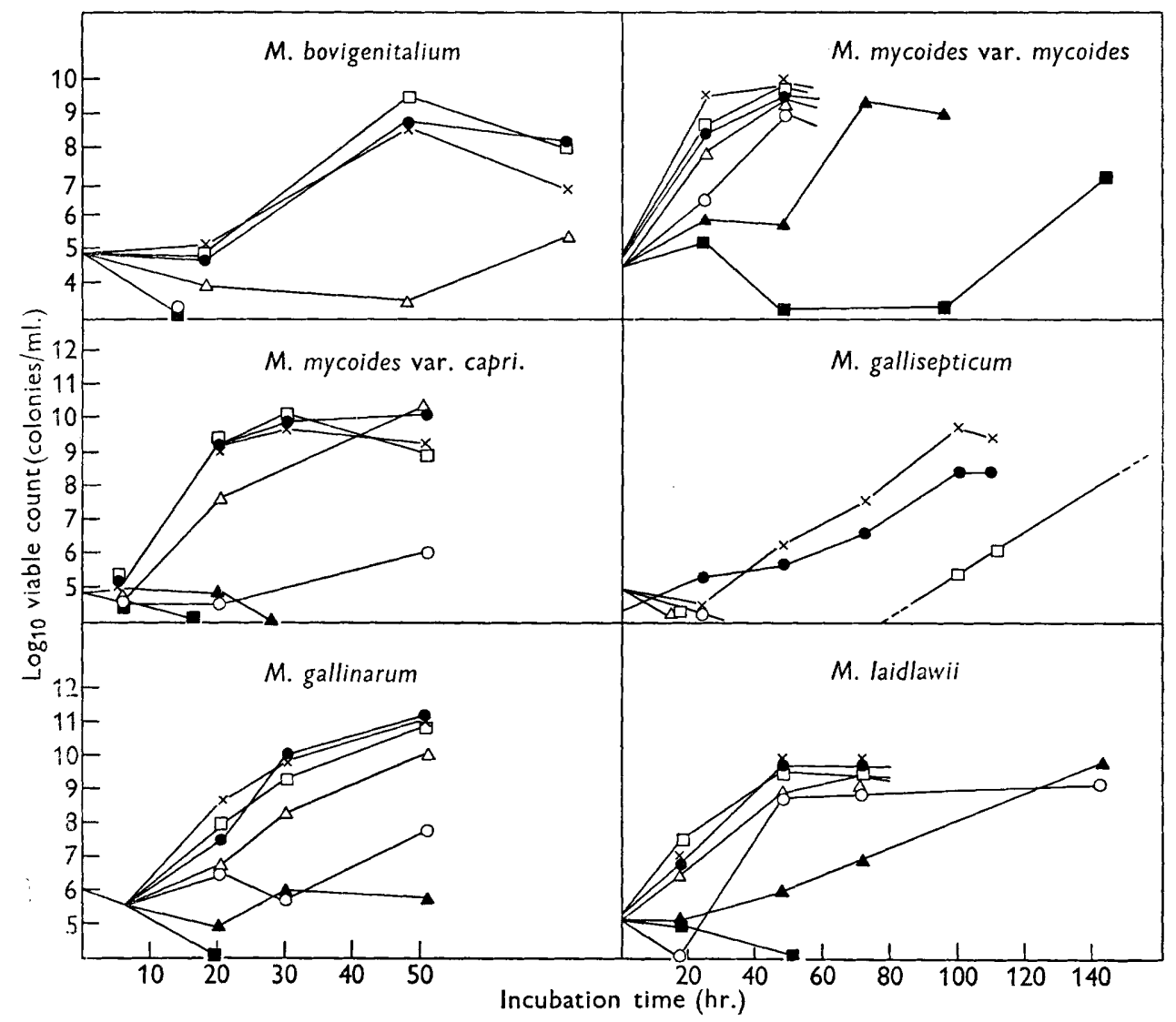

Fig. 1. Effect of tonicity of medium on growth of Mycoplasma. Growth of several species of Mycoplasma in dilute Edward medium after adjustment of tonicity with $\mathrm{NaCl}$ to $2.7(O), 4.1(\Delta), 6.8(\square), 10(\times), 14(\bullet), 27(\Delta)$, or $41(\square)$ atmospheres osmotic pressure.

\section{Groroth in fluid medium}

A number of Mycoplasma strains which showed sufficient growth from large inocula to be measured by nephelometry were tested in media of different osmotic strengths. Table 2 summarizes the results obtained from these experiments. The relation of growth rate and final opacity to the osmotic strength of the medium was very marked for all strains. This was supported by other experiments in which growth of smaller inocula was followed by viable counts (Fig. 1). With the exception of a laboratory strain of Mycoplasma mycoides var. mycoides, which gave rather variable results, the results obtained by nephelometry and by viable counts were strikingly similar. The optimal osmotic pressure was always between 6.8 and 14 atmospheres, usually about 10 atmospheres, which is slightly hypertonic in the physiological sense. Sensitivity to osmotic conditions differed greatly between various 
strains. $M$. gallisepticum did not grow outside the narrow range of 6.8-14 atmospheres, whereas for the saprophytic $M$. laidlawii the limits were $<2 \cdot 7-27$ atmospheres. Except for the laboratory strain of $M$. mycoides var. mycoides, only $M$. laidlawii showed multiplication, within the experimental period, at more than 14 atmospheres. Growth of $M$. mycoides var. mycoides was greatly retarded at 41 atmospheres, but in several other experiments no growth of this strain occurred at this value of tonicity (e.g. Table 5). For most species slightly suboptimal conditions resulted only in slower growth rates but greater extremes of tonicity sometimes prolonged the lag phase of growth (Fig. 1).

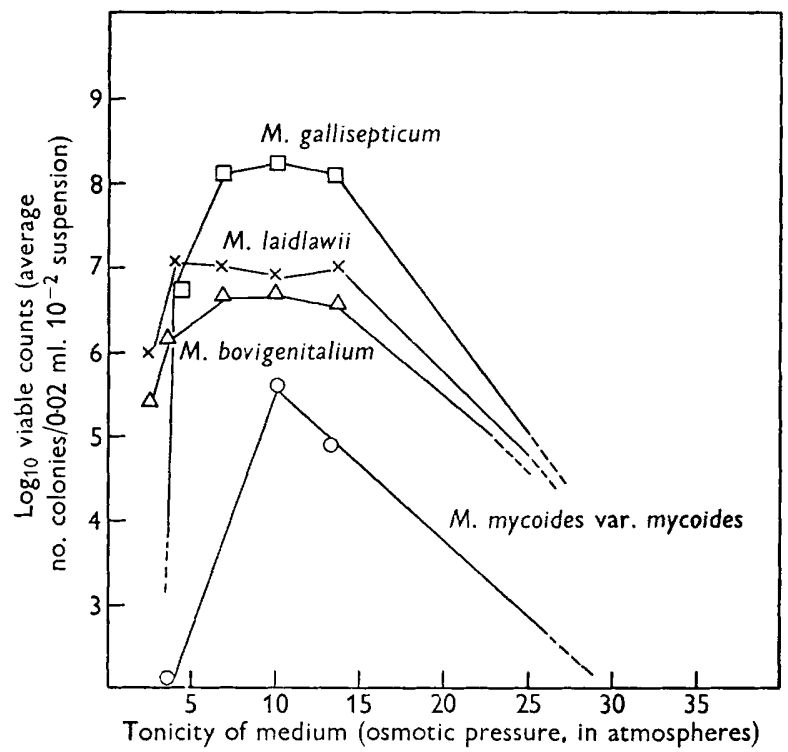

Fig. 2. Effect of tonicity of agar medium on colony counts of Mycoplasma suspensions.

\section{Growth on solid media}

Growth on solid media was estimated by the number of colonies produced from a given dilution of Mycoplasma suspension in 0.01 $\mathrm{M}$-phosphate-buffered ( $\mathrm{pH} \mathrm{7 \cdot 4}$ ) physiological saline. Preliminary tests showed that the tonicity of the fluid in which the inoculum was diluted had virtually no effect on the results. As with fluid medium, optimal growth of colonies was provided by an osmotic pressure of about 10 atmospheres (Fig. 2). Except for Mycoplasma mycoides var. mycoides, which was more sensitive to the tonicity on solid medium, the limiting osmotic conditions were similar to those found for growth in fluid medium.

The requirement for an optimal osmotic pressure of 10 atmospheres was confirmed under conditions of primary isolation when samples of milk from a cow suffering from a mastitis due to Mycoplasma bovigenitalium (Davidson \& Stuart, 1960) were plated at various dilutions on solid media of different tonicities (Table 3). At high inoculum dilutions this organism was even more exacting osmotically than the laboratory strain of $M$. bovigenitalium (Figs. 1, 2). 


\section{Adjustment of tonicity with solutes other than $\mathrm{NaCl}$}

To investigate the possibility that $\mathrm{NaCl}$ was required specifically, other solutes including $\mathrm{Na}_{2} \mathrm{SO}_{4}, \mathrm{KCl}$, sucrose and a balanced salts solution (see Methods), were used to increase the tonicity of dilute (solid) Edward medium (Table 1). The results of tests with three Mycoplasma strains are shown in Table 4. In general these showed the same relationship between the tonicity of the medium and colony counts as had been obtained in experiments with $\mathrm{NaCl}$ (Fig. 2). Growth was always maximal between $6 \cdot 8$ and 14 atmospheres osmotic pressure.

Table 3. Effect of tonicity of agar medium on primary isolation of Mycoplasma bovigenitalium from milk

\begin{tabular}{ccc}
$\begin{array}{c}\text { Osmotic pressure } \\
\text { of medium } \\
\text { (atmospheres) }\end{array}$ & $\begin{array}{c}\text { Average number of colonies } \\
\text { per } 0.02 \mathrm{ml} \text {. inoculum dilutions } \\
\text { after incubation at } 37^{\circ} \text { for } \\
\text { 10 days }\end{array}$ \\
\hline $2 \cdot 7$ & $10^{-3}$ & $10^{-4}$ \\
$4 \cdot 1$ & 0 & 0 \\
$6 \cdot 8$ & $1 \cdot 3$ & 0 \\
10 & 1000 & 10 \\
14 & 1000 & 150 \\
27 & 1000 & 110 \\
& 0 & 0
\end{tabular}

Table 4. Adjustment of tonicity of agar medium with solutes other than $\mathrm{NaCl}$

Scoring shows growth produced by $10^{-2}$ dilution of cultures of three Mycoplasma species.

Scoring: + About 10 colonies per 0.02 ml. inoculum. ++ About 100-1000 colonies per $0.02 \mathrm{ml}$. inoculum. +++ About or greater than 10,000 colonies per $0.02 \mathrm{ml}$. inoculum.

\begin{tabular}{|c|c|c|c|c|c|c|c|}
\hline \multirow{2}{*}{$\begin{array}{l}\text { Mycoplasma } \\
\text { species }\end{array}$} & \multirow[b]{2}{*}{ Solutes } & \multicolumn{6}{|c|}{ Osmotic pressure of medium (atmospheres) } \\
\hline & & $2 \cdot 7$ & $4 \cdot 1$ & $6 \cdot 8$ & 14 & 27 & $\mathbf{5 5}$ \\
\hline \multirow[t]{2}{*}{ M. laidlawii } & $\begin{array}{l}\mathrm{Na}_{2} \mathrm{SO}_{4} \\
\mathrm{KCl} \\
\text { Balanced } \\
\text { salts } \\
\text { mixture* }\end{array}$ & $\begin{array}{l}+++ \\
++t \\
+++\end{array}$ & $\begin{array}{l}+++ \\
+++ \\
+++\end{array}$ & $\begin{array}{l}+++ \\
+++ \\
+++\end{array}$ & $\begin{array}{l}+++ \\
+++ \\
++t\end{array}$ & $\begin{array}{l}0 \\
+++ \\
0\end{array}$ & $\begin{array}{l}0 \\
0 \\
0\end{array}$ \\
\hline & Sucrose & o & ++ & ++ & ++ & 0 & $\mathbf{0}$ \\
\hline \multirow[t]{2}{*}{$\begin{array}{l}\text { M. mycoides var. } \\
\text { mycoides }\end{array}$} & $\begin{array}{l}\mathrm{Na}_{2} \mathrm{SO}_{4} \\
\mathrm{KCl} \\
\text { Balanced } \\
\text { salts } \\
\text { mixture* }\end{array}$ & $\begin{array}{l}0 \\
0 \\
0\end{array}$ & $\begin{array}{l}++t \\
0 \\
0\end{array}$ & $\begin{array}{l}+++ \\
0 \\
+++\end{array}$ & $\begin{array}{l}+t+ \\
0 \\
++t\end{array}$ & $\begin{array}{l}0 \\
0 \\
0\end{array}$ & $\begin{array}{l}\mathbf{0} \\
\mathbf{0} \\
\mathbf{0}\end{array}$ \\
\hline & Sucrose & $\mathbf{0}$ & $\mathbf{0}$ & +++ & +++ & $\mathbf{0}$ & $\mathbf{0}$ \\
\hline \multirow[t]{2}{*}{ M. gallisepticum } & $\begin{array}{l}\mathrm{Na}_{2} \mathrm{SO}_{4} \\
\mathrm{KCl} \\
\text { Balanced } \\
\text { salts } \\
\text { mixture }\end{array}$ & $\begin{array}{l}+t \\
+t+ \\
+t+\end{array}$ & $\begin{array}{l}++ \\
+++ \\
+++\end{array}$ & $\begin{array}{l}+++ \\
+++ \\
+++\end{array}$ & $\begin{array}{l}+++ \\
+++ \\
+++\end{array}$ & $\begin{array}{l}0 \\
++ \\
0\end{array}$ & $\begin{array}{l}\mathbf{0} \\
\mathbf{0} \\
\mathbf{0}\end{array}$ \\
\hline & Sucrose & + & + & ++ & ++ & 0 & $\mathbf{0}$ \\
\hline
\end{tabular}

* $\mathrm{NaCl}: \mathrm{KCl}: \mathrm{Na}_{2} \mathrm{SO}_{4}: \mathrm{MgCl}_{2}$ in molal ratios 5:3:1:1 (Methods). 


\section{Adaptation of osmotic requirements}

Attempts were made to alter the osmotic requirements of the laboratory strain of Mycoplasma mycoides var. mycoides by continued subculture at different values of medium tonicity. From an experiment in which this strain showed multiplication at 27 atmospheres and at $\mathbf{2 \cdot 7}$ atmospheres in fluid medium, sublines were made and maintained for 12 twice-weekly subcultures at each of these respective values of tonicity, and also at optimal tonicity (10 atmospheres). The osmotic requirements, when tested in fluid medium at the end of this period, were very similar to those of the 'unadapted' strain (Table 5), except for a slightly diminished tolerance of hypertonic conditions shown by the organisms maintained at low tonicity and a slightly greater tolerance of hypertonicity by organisms maintained at high tonicity.

\section{Table 5. Effect of repeated subculture at different values of tonicity on} osmotic requirements of Mycoplasma mycoides var. mycoides

\begin{tabular}{|c|c|c|c|c|c|c|c|}
\hline \multirow{2}{*}{$\begin{array}{c}\text { Culture } \\
\text { maintained } \\
\text { at (atmos.): }\end{array}$} & \multicolumn{7}{|c|}{ Osmotic pressure of test medium (atmospheres) } \\
\hline & $\mathbf{2} \cdot 7$ & $4 \cdot 1$ & $6 \cdot 8$ & 10 & 14 & 27 & 41 \\
\hline & \multicolumn{7}{|c|}{ log. colonies $/ \mathrm{ml}$. } \\
\hline $\mathbf{2} \cdot 7$ & $0 \cdot 6$ & $\mathbf{2 \cdot 2}$ & $\mathbf{2 \cdot 7}$ & $1 \cdot 5$ & $\begin{array}{c}0^{*} \\
\text { delayed } \\
\text { growth }\end{array}$ & Decrease & Decrease \\
\hline 10 & 0 & 1.4 & $\mathbf{2} \cdot 0$ & $2 \cdot 0$ & $1 \cdot 8$ & Decrease & Decrease \\
\hline $27+$ & $\mathbf{2 \cdot 2}$ & $\mathbf{3 \cdot 2}$ & $4 \cdot 1$ & $3 \cdot 8$ & $\mathbf{3} \cdot \mathbf{1}$ & 0.5 & Decrease \\
\hline
\end{tabular}

* Still in log phase at $19 \mathrm{hr}$.

$\dagger$ A smaller inoculum was used; hence the increases at $19 \mathrm{hr}$. were greater than for the other two inocula.

\section{Effect of serum content of medium on osmotic requirements}

Mycoplasma laidlawii was able to grow in dilute Edward medium without serum, and its osmotic requirements remained the same under these conditions. Other species, however, failed to grow in the complete absence of serum, irrespective of the tonicity of the medium. The effect of decreased serum concentrations was examined for one such species, $\boldsymbol{M}$. bovigenitalium, which in dilute Edward medium (containing $8 \%, \mathrm{v} / \mathrm{v}$, serum) was able to grow only at osmotic pressures of between $4 \cdot 1$ and 14 atmospheres (Fig. 1; Table 2). Equivalent suspensions of this organism were inoculated into dilute Edward medium in which the serum content was varied between 0.25 and $16 \%(\mathrm{v} / \mathrm{v})$. Osmotic pressure was adjusted to $4 \cdot 1,6 \cdot 8$ and 10 atmospheres, growth at 14 atmospheres having been found in a preliminary experiment to be almost identical with that at 10 atmospheres for all serum concentrations.

Growth curves for each medium indicated an interrelationship between the serum content of the medium, its tonicity, and the growth rate of Mycoplasma bovigenitalium (Fig. 3). At the highest serum concentrations the rates at $6 \cdot 8$ and 10 atmospheres were similar, while growth at $4 \cdot 1$ atmospheres was moderate but sub-optimal. With 
decreasing serum concentration the differences in growth at the three tonicity values became more marked. Thus in $1 \%(\mathrm{v} / \mathrm{v})$ serum medium growth at 10 atmospheres was still nearly optimal; it was appreciably slower at $6 \cdot 8$ atmospheres and at $4 \cdot 1$ atmospheres had decreased to zero. At $0.25 \%$ of serum, growth at 10 atmospheres had diminished markedly while that at $6 \cdot 8$ atmospheres was almost at zero value.

\section{Effect of spermine}

The polyamine spermine, which protects certain bacteria against adverse osmotic conditions (Mager, 1959), had no effect on the osmotic requirements of three Mycoplasma species growing in fluid media. Mycoplasma gallisepticum was tested with $2 \mu \mathrm{M}, M$. gallinarum with $0 \cdot 4 \mu \mathrm{M}$, and $M$. bovigenitalium at $0 \cdot 2-20 \mu \mathrm{M}$ spermine phosphate.

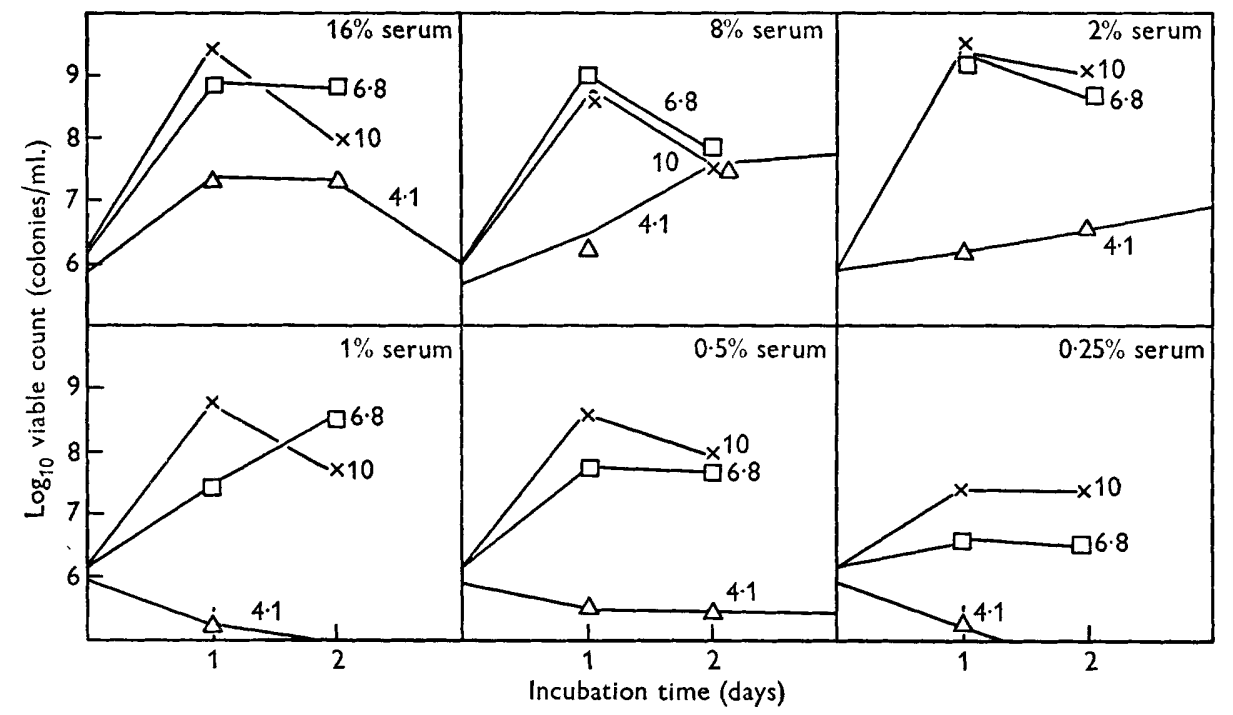

Fig. 3. Effect of serum concentration on growth of Mycoplasma bovigenitalium in fluid medium of different tonicities. Numbers adjacent to each growth curve refer to tonicity of medium expressed as osmotic pressure (atmospheres).

\section{DISCUSSION}

The above experiments with several species of Mycoplasma confirm the suggestion of Adler \& Shifrine (1960), based on their own observations with avian Mycoplasma and on those of Rodwell (1956) with Mycoplasma mycoides var. mycoides, that this group can multiply in artificial media only within very restricted values of tonicity and has an optimal osmotic pressure requirement of about 10 atmospheres. The upper limit for growth appears to be about 27 atmospheres for $M$. laidlawii and usually 14 atmospheres for non-saprophytic strains. The lower limits are wider, several strains being able to grow sub-optimally at about $2 \cdot 7$ atmospheres, with sensitive strains such as $\boldsymbol{M}$. gallisepticum and $\boldsymbol{M}$. maculosum unable to multiply at less than 6.8 atmospheres. When expressed as water activity (Table 1 ) these limits (upper $0.990-0.980 a_{w}$; lower 0.998-0.995 $a_{w}$ ) are seen to be much narrower than those for a wide range of bacteria as compiled by Scott (1956). Even a very delicate bacterial species such as Vibrio metchnikovi is capable of multiplication between 
0.970 and $0.999 a_{w}$ (Marshall \& Scott, 1958). The fact that Mycoplasma strains are more exacting in osmotic requirements than bacteria is consistent with their lack of a rigid cell wall. It is of interest that initial viable counts made 5-15 min. after inoculation of fluid media of varying tonicity were very similar (Fig. 1), suggesting that these organisms suffered little osmotic shock in any of these media. This is in accord with suggestions that the group is less susceptible to osmotic shock than is generally supposed (Smith \& Sasaki, 1958; Butler \& Knight, 1960 a; Adler \& Shifrine, 1960). Plackett (1959) pointed out that the disruptive forces due to a hypotonic environment could be relatively slight for organisms as small as Mycoplasma. Such forces should be expected to be more critical during growth and division of cells and it is, therefore, not surprising that the tonicity of the medium should be much more important for actual multiplication. It is not clear, however, whether the slower rates of multiplication at sub-optimal tonicities in the present experiments were due to death of a proportion of cells during or after division, or to impaired metabolism of all the cells in a culture under these conditions.

It may be significant that Mycoplasma laidlawii, which is able to grow without serum, had the least exacting osmotic requirements of the strains tested (Fig. 1). This is consistent with the fact that for one of the more exacting species, M. bovigenitalium, there was an interrelationship between serum concentration and tonicity requirements. High serum concentrations were necessary for growth in medium of low tonicity and hypertonic conditions for optimal growth at lower serum concentrations (Fig. 3). This relationship suggests that at least a partial role of serum is that of protection against adverse osmotic conditions. Rodwell (1956) showed that serum components, including cholesterol, protect suspensions of M. mycoides var. mycoides against lysis by surface-active substances. Further work on the osmotic effect of various components of serum, including cholesterol, which is a specific growth factor for Mycoplasma (Edward, 1954), may help to elucidate their role in the nutrition of this group of organisms.

From the practical point of view it is interesting that a newly isolated strain of Mycoplasma bovigenitalium showed much the same osmotic requirements as the laboratory lines of Mycoplasma (Table 3). This observation, together with the failure of subcultivation at extremes of tonicity to change the optimal osmotic requirements of $M$. mycoides var. mycoides, suggests that the special osmotic requirements of our laboratory strains of Mycoplasma are not simply a result of adaptation to the slightly hypertonic Edward medium.

I am indebted to Dr D. G. ff. Edward for his advice and encouragement throughout this work. I should also like to thank Dr J. H. B. Christian for advice on calculations of tonicity of media, Dr M. Butler for helpful discussions and criticism of the manuscript and Mrs M. Brereton for her valuable technical assistance.

\section{REFERENCES}

Adler, H. E. \& Shrfrine, M. (1960). Nutrition, metabolism and pathogenicity of Mycoplasmas. Annu. Rev. Microbiol. 14, 141.

Butier, M. \& Knight, B. C. J. G. (1960a). The survival of washed suspensions of Mycoplasma. J. gen. Microbiol. 22, 470. 
Butler, M. \& Knight, B. C. J. G. (1960b). The measurement of the growth of Mycoplasma in liquid media. J. gen. Microbiol. 22, 478.

Chu, H. P., Honne, R. W. \& Cosslett, V. E. (1956). The electron micrography of pleuropneumonia-like organisms. Proc. 3rd Int. Conf. on Electron Microscopy. London: Royal Microscopical Society.

Davidson, I. \& Stuart, P. (1960). Isolation of a Mycoplasma-like organism from an outbreak of Bovine Mastitis. Vet. Rec. 72, 766 .

EDWARD, D. G. FF. (1950). An investigation of pleuropneumonia-like organisms isolated from the bovine genital tract. J. gen. Microbiol. 4, 4 .

EDWARD, D. G. FF. (1954). The pleuropneumonia group of organisms: A Review, together with some new observations. J. gen. Microbiol. 10, 27.

Edward, D. G. FF. \& Freundt, E. A. (1956). The classification and nomenclature of organisms of the pleuropneumonia group. J. gen. Microbiol. 14, 197.

Freundt, E. A. (1952). Morphological studies of the peripneumonia organism (Micromyces peripneumoniae bovis). Acta path. microbiol. Scand. 31, 508.

Handbook of Chemistry \& Physics (1958), 40th ed. Editor-in-Chief, C. D. Hodgman. Cleveland, Ohio, U.S.A.: Chemical Rubber Publishing Co.

KANDLER, O. \& ZEHENDER, C. (1957). Über das Vorkommen von $\alpha, \epsilon$-Diaminopimelinsäure bei verschiedenen L-phasentypen von Proteus vulgaris und bei den pleuropneumoniaähnlichen Organismen. Z. Naturf. $12 b, 725$.

KLIENeberger, E. \& Suiles, J. (1942). Some new observations on the developmental cycle of the organism of bovine pleuropneumonia and related microbes. J. Hyg., Camb. $42,110$.

KliEneberger-Nobel, E. (1954). Microorganisms of the pleuropneumonia group. Biol. Rev. 29, 154.

Klieneberger-Nobel, E. \& Cuckow, F. W. (1955). Further studies of organisms of the Pleuropneumonia group by electron microscopy. J. gen. Microbiol. 13, 149.

MAGER, J. (1959). Spermine as a protective agent against osmotic lysis. Nature, Lond. 183. 1827.

Marshall, B. J. \& ScotT, W. J. (1958). The water relations of Vibrio metchnikovi at $30^{\circ} \mathrm{C}$. Aust. J. biol. Sci. 11, 171.

Plackett, P. (1959). On the probable absence of 'mucocomplex' from Mycoplasma mycoides. Biochim. biophys. Acta, 35, 260.

Robinson, R. A. \& Stokes, R. H. (1955). Electrolyte Solutions. New York: Academic Press.

RoDwell, A. W. (1956). The role of serum in the nutrition of Asterococcus mycoides. Aust. J. biol, Sci. 9, 105.

Scotт, W. J. (1953). Water relations of Staphylococcus aureus at $30^{\circ} \mathrm{C}$. Aust. J. biol. Sci. $6,549$.

Scotr, W. J. (1956). Water relations of food spoilage microorganisms. Advanc. Food Res. $7,83$.

Smrth, W. E., Hrulier, J. \& Mudd, S. (1948). Electron micrographic studies of two strains of pleuropneumonia-like $(L)$ organisms of human derivation. J. Bact. 56, 589.

Sмiтh, P. F. \& SASaki, S. (1958). Stability of pleuropneumonia-like organisms to some physical factors. App. Microbiology, 6, 184. 